\title{
The first detection of SARS-CoV-2 RNA in the wastewater of Tehran, Iran
}

\author{
Mohammad Tanhaei $^{1}$ - Seyed Reza Mohebbi ${ }^{2} \cdot$ Seyed Masoud Hosseini ${ }^{3} \cdot$ Maedeh Rafieepoor $^{1}$. \\ Shabnam Kazemian ${ }^{2} \cdot$ Amir Ghaemi $^{4} \cdot$ Sharareh Shamloei ${ }^{5} \cdot$ Hamed Mirjalali $^{6} \cdot$ Hamid Asadzadeh Aghdaei $^{1}$. \\ Mohammad Reza Zali ${ }^{2}$
}

Received: 13 December 2020 / Accepted: 8 March 2021 / Published online: 18 March 2021

(C) The Author(s), under exclusive licence to Springer-Verlag GmbH Germany, part of Springer Nature 2021

\begin{abstract}
Following the official announcement of severe acute respiratory syndrome coronavirus 2 (SARS-CoV-2) worldwide pandemic spread by WHO on March 11, 2020, more than 300,000 COVID-19 cases reported in Iran resulting in approximately 17,000 deaths as of August 2, 2020. In the present survey, we investigated the presence of SARS-CoV-2 RNA in raw and treated wastewater samples in Tehran, Iran. Untreated and treated wastewater samples were gathered from four wastewater treatment plants over a month period from June to July 2020. Firstly, an adsorption-elution concentration method was tested using an avian coronavirus (infectious bronchitis virus, IBV). Then, the method was effectively employed to survey the presence of SARS-CoV2 genome in influent and effluent wastewater samples. SARS-CoV-2 RNA was found in 8 out of 10 treated wastewater samples utilizing a reverse transcription-quantitative polymerase chain reaction (RT-qPCR) test to detect ORF1ab and N genes. Moreover, the rate of positivity in wastewater samples increased in last sample collection that shows circulation of SARSCoV-2 was increased among the population. In addition, the high values detected in effluent wastewater from local wastewater treatment plants have several implications in health and ecology that should be further assessed.
\end{abstract}

Keywords SARS-CoV-2 $\cdot$ COVID-19 $\cdot$ Wastewater $\cdot$ Influent water $\cdot$ Effluent $\cdot$ Iran

\section{Introduction}

Coronavirus disease 2019 (COVID-19) is the ongoing global pandemic, caused by severe acute respiratory syndrome coronavirus 2 (SARS-CoV-2) and was first described in Wuhan, China, in December 2019 (WHO 2020b). From the first detected case, in less than 6 months, SARS-CoV-2 has caused approximately 14 million infections and more than half a

Responsible Editor: Lotfi Aleya

Seyed Reza Mohebbi

sr.mohebbi@sbmu.ac.ir

$1 \quad$ Basic and Molecular Epidemiology of Gastrointestinal Disorders Research Center, Research Institute for Gastroenterology and Liver Diseases, Shahid Beheshti University of Medical Sciences, Tehran, Iran

2 Gastroenterology and Liver Diseases Research Center, Research Institute for Gastroenterology and Liver Diseases, Shahid Beheshti University of Medical Sciences, Arabi str., Yaman Ave., Velenjak, Tehran, Iran million deaths. Initial COVID-19 in Iran was reported on February 19, 2020, followed by the first reported case in Tehran on February19, 2020 (WHO 2020a).

The name "coronavirus" is derived from a Latin word "corona," meaning "crown" or "wreath," due to the morphology of the virus, the name has been given. This morphology is formed by the viral spike peplomers that are proteins on the virus envelope. These surface proteins are involved in several

3 Department of Microbiology and Microbial Biotechnology, Faculty of Life Sciences and Biotechnology, Shahid Beheshti University, Tehran, Iran

4 Department of Virology, Pasteur Institute of Iran, Tehran, Iran

5 Department of Water and Wastewater Quality Control Laboratory, Water and Wastewater Company, Tehran, Iran

6 Foodborne and Waterborne Diseases Research Center, Research Institute for Gastroenterology and Liver Diseases, Shahid Beheshti University of Medical Sciences, Tehran, Iran 
features of the virus life cycle, such as assembly, envelope formation, and pathogenesis. Inside the envelope is the helical capsid holding nucleoprotein and the RNA genome. The coronavirus genome is encoded in a positively polarized RNA strand of approximately 30,000, making it the largest known RNA virus with a non-fragmented genome (Mlejnkova et al. 2020)

Coronavirus infection can lead to mammals and avian diseases. In humans, they are commonly responsible for mild to severe respiratory involvement and even death in some cases. Some of the coronaviruses can cause mild disease like common cold, on the other hand, other coronaviruses including SARS, MERS, and COVID-19 may create lethal diseases. The symptoms of COVID-19 patients include cough, fever, and difficulty in breathing; moreover, $2-10 \%$ of them had gastrointestinal symptoms, comprehend diarrhea (Cai et al. 2020; Gao et al. 2020; Holshue et al. 2020; Liu et al. 2020; Tang et al. 2020; Wölfel et al. 2020; Zhang et al. 2020a, b). Side effects of COVID-19 disease include changing or even losing of smell and taste senses, nausea, sore throat, body aches, and headache (NCIRD 2021).

The main transmission route of SARS-CoV-2 is through respiratory secretion droplet generation during breathing, sneezing, coughing, and also direct/indirect contact. Though, the genomic RNAs of these viruses have been found in patients stool and also urine specimens. Recent publications revealed that SARS-CoV-2 RNA has also been detected in feces and anal/rectal swabs (Cai et al. 2020; Gao et al. 2020; Holshue et al. 2020; Tang et al. 2020; Wölfel et al. 2020; Xiao et al. 2020; Zhang et al. 2020a, b). Wang and colleagues found that SARS-CoV-2 RNA could be isolated from stool samples in around $29 \%$ of patients (Wang et al. 2020a, b, d; Xiao et al. 2020). Also SARS-CoV-2 RNA has been more seen in fecal samples from hospitalized patients. Even after resolution of respiratory symptoms, persistence shedding of viral RNA in stool samples continues in some cases (Xiao et al. 2020). In addition, the scale of the virus shedding may vary widely from $10^{2}$ up to $10^{8}$ RNA copies per gram (Lescure et al. 2020; Pan et al. 2020; Wölfel et al. 2020). These studies recommended that viral fecal shedding could persist for several days in individuals without gastrointestinal symptoms. Therefore, asymptomatic individuals with negative nasopharyngeal test result may disperse SARS-CoV-2 into the environment (Jiang et al. 2020). Also a recent study suggests that SARS-CoV-2 remains in the stool (medium, 22 days) longer than the respiratory form (18 days) (Zheng et al. 2020).

As public urban wastewater network collects significant amounts of symptomatic and asymptomatic patients' feces, SARS-CoV-2 might be found for approximately a long period of time in public wastewater pipe network, becoming a secondary spreading source. In addition, treated sewage from hospitals also adds a notable risk of SARS-CoV-2 accumulation into sewage collection systems. Consequently, in addition to direct contact and respiratory droplets, fecal-oral spread route can be another important transmission route to increasing the virus circulation in different populations.

Recently, the presence of SARS-CoV-2 RNA has been reported in wastewater treatment plants in Australia, Italy, Spain, the Netherlands, USA, Japan, Germany, UAE, Istanbul, and Brazil (Ahmed et al. 2020a, Haramoto et al. 2020, La Rosa et al. 2020a, b, Medema et al. 2020, Randazzo et al. 2020b, Sherchan et al. 2020, Prado et al. 2021, Kocamemi et al. 2020, Westhaus et al. 2021, Albastaki et al. 2020) and some studies have also examined the presence of this virus in river water (Rimoldi et al. 2020a; Haramoto et al. 2020; Guerrero-Latorre et al. 2020).

Method for concentration and detection of SARS-CoV-2 was one of the main technical challenges in WBE studies (Ahmed et al. 2020b). Due to the difference between recovery and detection in enveloped and non-enveloped viruses, SARS-CoV-2 as an enveloped virus, we have a lack of information about its recovery in wastewater. Recent studies have used several virus concentration methods to recover and accumulate SARS-CoV-2 from wastewater. According to recent studies, different recovery methods such as centrifugal ultrafiltration device (Medema et al. 2020; Ahmed et al. 2020a), the adsorption-extraction technique utilizing electronegative membrane (La Rosa et al. 2020a, b), a two-phase PEG-dextran method, and aluminum hydroxide adsorption-precipitation technique (Randazzo et al. 2020b) have been recently applied.

Based on this background and our previous study on Torque teno virus (TTV) in a wastewater treatment plant in Tehran (Tavakoli Nick et al. 2019), in the present study, we investigated the presence of SARS-CoV-2 RNA and demonstrated the first report of the presence of it in untreated and treated wastewater samples in Iran collected from four different wastewater treatment plants (WWTPs) in Tehran.

\section{Materials and methods}

\section{Collection of water samples}

Eleven samples were collected between the 30th of June and the 31 st of July 2020, from four WWTPs, located in Tehran (four distinct plants, reported as A, B, C, and D, respectively). A total of eleven samples were collected, including one sample from the input of one of the WWTPs and ten samples from the final effluent of each WWTP. Samples were collected in sterilized 4-L plastic bottles taking precautionary measures and transported to the Virology Laboratory in Research Institute for Gastroenterology and Liver Diseases, Shahid Beheshti University of Medical Sciences, Tehran, Iran, on ice and processed within $6 \mathrm{~h}$ of collection. 


\section{Virus concentration}

Viruses in samples were concentrated by an adsorptionelution method using an electronegative filter (Katayama et al. 2002). Briefly, $2.5 \mathrm{M} \mathrm{MgCl}_{2}$ was included to the sample to reach to a final concentration of $25 \mathrm{mM}$. Then, 1-L effluents and 200-mL influent were filtered using a six-branch filtration system (Sartorius, Goettingen, Germany) and sterile 47-mm cellulose nitrate membrane (Sartorius, Goettingen, Germany) with pore size $0.45 \mu \mathrm{m}$. Afterwards, the filter was rinsed with $200 \mathrm{~mL}$ of $0.5 \mathrm{mM} \mathrm{H}_{2} \mathrm{SO}_{4}(\mathrm{pH} 3.0$ ) followed by elution of the viruses from the membrane filter using $10 \mathrm{~mL}$ of $1.0 \mathrm{mM}$ $\mathrm{NaOH}(\mathrm{pH} 10.8)$. The filtrate was recovered as a primary concentrate in a vessel containing $50 \mu \mathrm{L}$ of $100 \mathrm{mM} \mathrm{H}_{2} \mathrm{SO}_{4}$ and $100 \mu \mathrm{L}$ of $100 \times$ Tris-EDTA buffer. Eluates containing viruses were further concentrated by polyethylene glycol (PEG-6000, Merck, Darmstadt, Germany) precipitation method as described previously (Vilagines et al. 1997) with some modifications. In brief, $12.5 \%$ PEG-6000 and $2.5 \% \mathrm{NaCl}$ at final concentration were included, the eluate was mixed at 4 ${ }^{\circ} \mathrm{C}$ for $2 \mathrm{~h}$ and centrifuged at $10,000 \times \mathrm{g}$ for $30 \mathrm{~min}$. The pellet was suspended in $200 \mu \mathrm{L}$ of PBS (pH 7.2) and the suspension was stored at $-20^{\circ} \mathrm{C}$ until used (Fig. 1).

\section{Viral RNA extraction}

Viral nucleic acids were extracted from $140 \mu \mathrm{L}$ of the final elute obtained from the second concentration step using a QIAamp RNA mini kit (Qiagen, Germany) according to the manufacturer's protocol. The extracted nucleic acid was kept at $-20{ }^{\circ} \mathrm{C}$ until additional downstream analysis.

\section{RT-qPCR analysis}

The occurrence of SARS-CoV-2 RNA in wastewater was detected by real-time reverse transcription polymerase chain reaction (RT-qPCR) using the kits of Sansure Biotech Inc. (Changsha, China) and Shanghai Zhijiang Biotechnology Co. (Shanghai, China), according to the manufacturer's instructions and quantitative analysis of gene $\mathrm{N}$ individually conducted with probes and primers.
In quantitative analysis, the standard curve was plotted according to different dilutions of in vitro transcription RNA (N gene). Specificity of the assay targeting two parts of the SARS-CoV-2 genome is declared by the manufacturer. Samples with a cycle quantification value $(\mathrm{Cq})$ $<40$ were considered positive. For positive and negative controls of PCR, the positive control kit, containing in vitro transcriptional RNA target genes (ORF1ab, N gene) and its internal standard gene fragments (Rnase $\mathrm{P}$ ), and negative control, namely normal saline, were used. Amplification and fluorescence detection were performed on a Rotor-Gene ${ }^{\circledR}$ Q (Qiagen, Germany).

\section{Result}

Among the eleven wastewater samples which were tested, the amplification of SARS-CoV-2 RNA genes ORF1ab and N was successful in the influent of one of the WWTPs on June 30th, 2020. Moreover, ten samples were gathered from WWTP A, WWTP B, WWTP C, and WWTP D outlets on three separate sampling events $(10 / 07 / 2020,21 / 07 / 2020$, and $31 / 07 / 2020$ ) which all were positive for SARS-CoV-2 except of WWTP A that means the $80 \%$ (8 positive samples out of 10) of effluent samples were tested positive for both SARSCoV-2 RT-qPCR targets (Table 1). Samples were considered positive for $\mathrm{Ct}$ below 40. Ct values ranged from 29.62 to 34.45 (ORF1 ab) and 27.60 to $30.53(\mathrm{~N})$, respectively. Positive samples that were quantitatively evaluated for the $\mathrm{N}$ gene were RNA copies found in them ranging from 7.18E + 01 to $1.09 \mathrm{E}$ $+03 \mathrm{GC} / \mathrm{mL}$ (Fig. 2). The modified electronegative method was tested by spiking effluent with IBV. On average, IBV was recovered at ranges of $11.78 \pm 1.76$.

\section{Discussion}

Characteristically, concentrating enteric viruses from wastewater and environmental waters was done by adsorption-elution method based on electronegative membrane. Thus, electronegative membrane is one of the

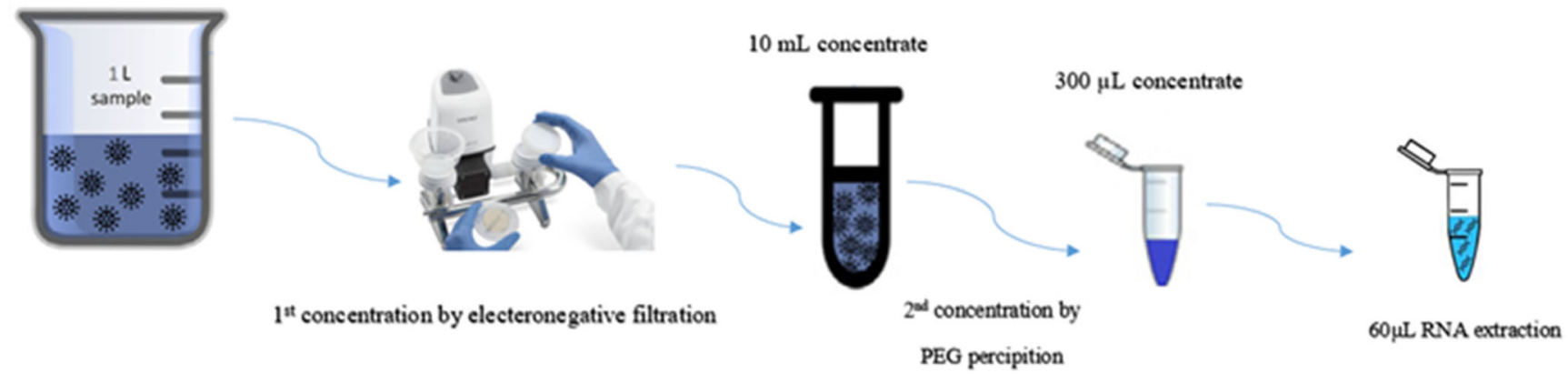

Fig. 1 Different stages of virus concentration method 
Table $1 \mathrm{Ct}$ values of real-time PCR amplification of SARSCoV-2, as obtained for WWTPs. Genes code refers to the $\mathrm{N}$ gene and Orflab gene

\begin{tabular}{lllllll}
\hline Sample origin & Station & Treatment & Date & \multicolumn{2}{l}{ Gene positivity } & \\
\cline { 4 - 6 } & & & & Orflab & N & \\
\hline WWTPs & A & Raw & June 30th & 29.62 & 29.96 & Positive \\
& A & Treated & & - & - & Negative \\
& B & Treated & July 10th & 33.76 & 30.53 & Positive \\
& C & & & 31.66 & 28.39 & Positive \\
& D & & 33.33 & 30.42 & Positive \\
B & Treated & July 21st & 33.96 & 30.10 & Positive \\
& C & & 34.45 & 30.39 & Positive \\
& A & Treated & July 31st & - & - & Negative \\
B & & & 30.78 & 27.85 & Positive \\
C & & & 33.65 & 30.13 & Positive \\
& D & & 30.61 & 27.60 & Positive \\
\hline
\end{tabular}

suitable candidates for concentrating enveloped viruses. Previous studies confirmed that utilizing the electronegative membrane provides a superior adsorption of enveloped viruses such as Pseudomonas phage $\$ 6$ and mouse hepatitis virus to the solid fraction of wastewater compared to non-enveloped viruses ( $\mathrm{Ye}$ et al. 2016). Other than electronegative membranes, the polyethylene glycol (PEG) has been extensively applied to reconcentrating SARS-CoV-2 in wastewater samples. On the other hand, just one study to date has reported the percent recovery of SARS-CoV from wastewater which was estimated to be only $1 \%$ using an electropositive membrane (Wang et al. 2005). Meanwhile, the differences between SARS-CoV-2 and enteric viruses showed that more research is necessary for the effective recovery of SARS-CoV-2 from wastewater.

In the current investigation, we used an enveloped virus, namely, avian coronavirus (IBV), for the detection of
SARS-CoV-2 in wastewaters. Avian coronavirus (IBV) is a member of Coronaviridae family that infects birds, causing the associated disease avian infectious bronchitis (IB). It is a highly contagious avian pathogen which influences on the respiratory tract, kidney, gut, and reproductive systems of chickens (Casais et al. 2001; Cavanagh 2001). IBV belongs to the genus Gammacoronavirus (Bande et al. 2016), or group 3 (Cavanagh 2007), with a singlestranded RNA genome. The mean recovery efficiency was acceptable, representative that there was no considerable inhibition or loss occurred during the RNA extraction and RT-qPCR (Acevedo et al. 2013), moreover electronegative membrane was satisfactory as a concentration method for an enveloped virus.

Recently, SARS-CoV-2 RNA in influent water has been detected and described worldwide (Ahmed et al. 2020a; La Rosa et al. 2020a, b; Lodder and de Roda Husman 2020; Medema et al. 2020; Nemudryi et al. 2020; Randazzo et al.
Fig. 2 SARS-CoV-2 specific RNA fragment detected by $\mathrm{N}$ gene RT-qPCR in the effluents. Results of a single PCR measurement are shown for $\mathrm{N}$ gene. For $\mathrm{N}$ gene RT-qPCR, CT values for the standard ranged between 21.8 (standard $1=10^{6}$ ) and 32.6 (standard $4=10^{3}$ ). Values of tested wastewater above CT 40 were considered negative for SARS-CoV-2

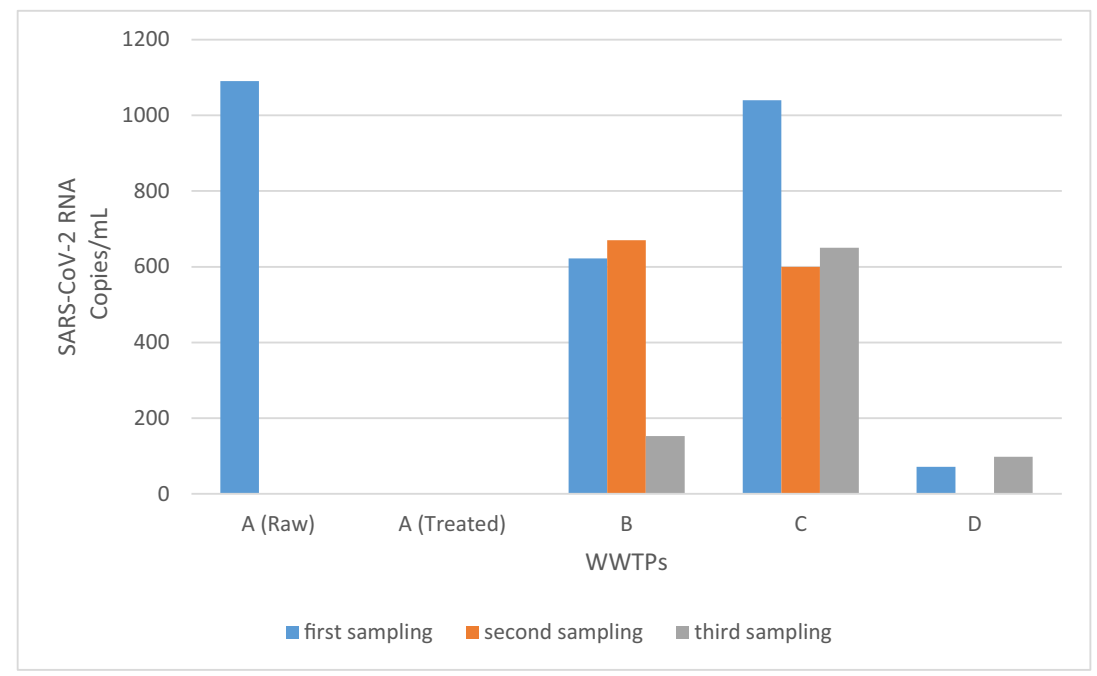




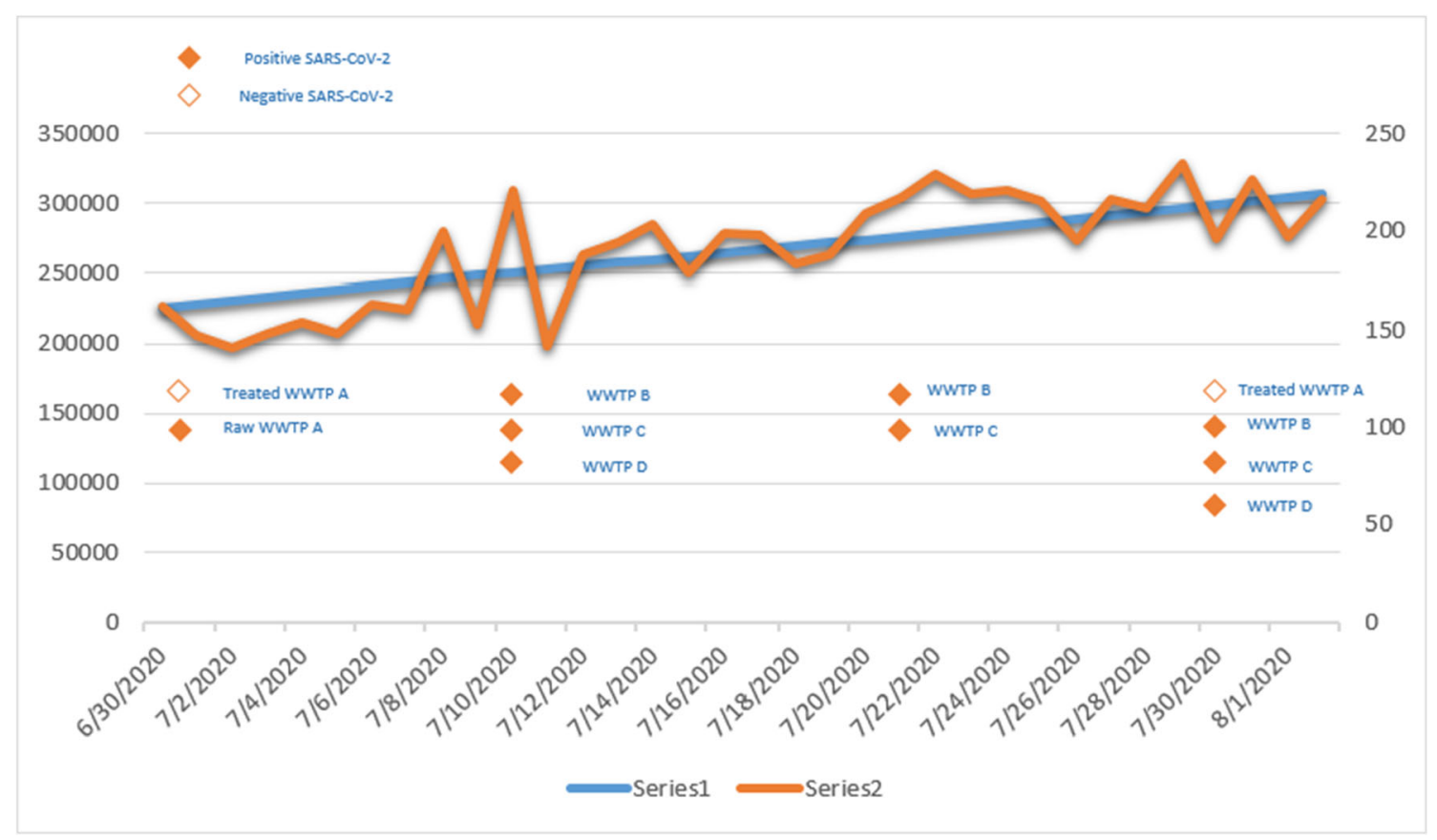

Fig. 3 SARS-CoV-2 RNA detection in wastewater and cumulative confirmed cases and new deaths in Iran. Squares represent sampling dates and sampling type (raw and treated wastewater). Orange filled squares denote positive SARS-CoV-2 RNA detection from WWTPs. Orange and blue line plots denote new deaths and cumulative established COVID-19 cases, respectively

presence of the virus in all influent and effluent samples of treatment plants. Therefore, in this study our focus was on effluent and just grabbed one raw wastewater to confirmed presence of the SARS-CoV-2. Of the eleven wastewater samples tested, SARS-CoV-2 RNA was not detected only in $20 \%(2 / 10)$ of effluent wastewater samples by Sansure COVID-19 RT-qPCR, which had been collected from WWTP A (Fig. 3).

The concentration of SARS-CoV-2 in the effluent in this study $\left(10^{1}\right.$ to $\left.10^{3} \mathrm{GC} / \mathrm{mL}\right)$ is almost similar to other studies such as the one conducted in Germany (Westhaus et al. 2020).
Fig. 4 Concentration of SARSCoV-2 RNA in wastewater as determined by the ORF1ab gene assay in cycle threshold (Ct value) against the number of new reported COVID-19 cases in the wastewater catchment for all WWTPs combined. Blue line plots denote new established COVID-19 cases and orange, gray, and yellow line plots denote site $\mathrm{B}, \mathrm{C}$, and $\mathrm{D}$, respectively

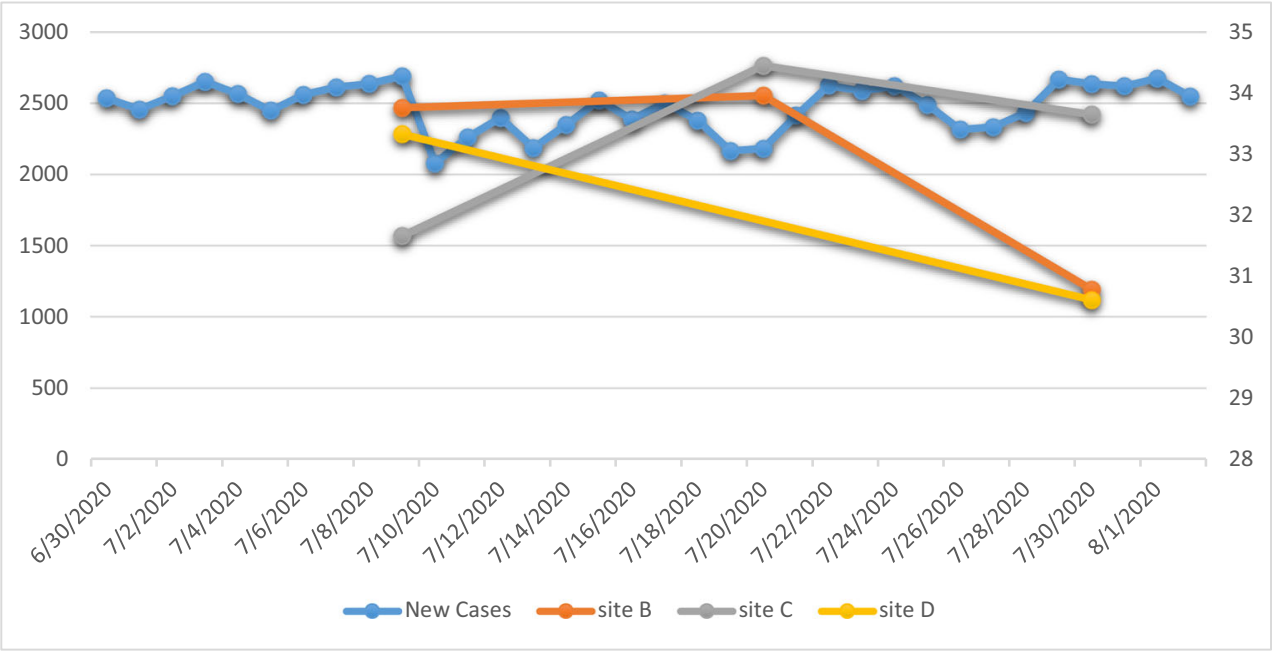


Of course, the wider range of the presence of the virus in the sewage indicates changes in the number of patients in different time periods.

These results show that wastewater treatment in main WWTPs, such as WWTP A, is performed correctly, unlike local wastewater treatment plants. Meanwhile, the local wastewater treatment plant discharges its treated effluent into urban rivers and canals. Consequences of this occurrence included; first, there is a risk of infection for the population in contact with downstream water due to the presence of SARSCoV-2, like other microbial pathogens, which is discharged into open river water. In addition, the persistence of SARSCoV-2 RNA in water can cause the recirculation of COVID19 in our communities. However, it is noteworthy that only genomic material has been identified in the wastewater, the detection of viable and the titer of the intact virus are essential in contaminated wastewater need to be determined, and also its ability to transmit through fecal-oral route has not yet been established. Second, the transmission of the virus in the environment has an unknown effect on the food safety such as vegetables and other foods that are eaten raw, through them can cause further spread of the disease.

Nowadays, in the second peak of COVID-19 pandemic in Iran, comparison of the average level of SARS-CoV-2 genomes in the last wastewater samples with the earlier wastewater samples confirmed that the increase of viral genome in effluent perfectly monitored the increase in the number of new cases confirmed in the country on the onset of the second peak of COVID-19 (Fig. 4).

\section{Conclusion}

In this study, raw and treated wastewater samples were collected from 4 treatments plants in Tehran and concentrated by membrane filtration and PEG perception. Meanwhile, raw wastewater along with 8 treated wastewater samples were infected with SARS-CoV-2 virus. Given these results, as well as the discharge of effluents from these treatment plants into rivers and urban canals, it warns governments to have more oversight and control over the performance of urban and local treatment plants.

Acknowledgements The present study was funded by the Research Institute for Gastroenterology and Liver Diseases, Shahid Beheshti University of Medical Sciences, Tehran, Iran. The authors would like to appreciate the RIGLD laboratory staff especially Mrs. Mahsa Saeedi Niasar.

Author contribution SMH, MRZ, and SRM conceived the study; MT, MR, and SHSH performed the sample and data collection; MT, MR, SHK, and SRM carried out the laboratory and molecular tests; MT, $\mathrm{HM}, \mathrm{AG}$, and SRM carried out the interpretation and analyze of the data; MT, MR, and SMH drafted the manuscript; and SRM, AG, HAA, and
MRZ critically revised the manuscript for intellectual content. All authors read and approved the final manuscript.

Data availability The datasets generated and/or analyzed during the current study by the authors is at the disposal of the corresponding author, which will be published upon reasonable request.

\section{Declarations}

Ethics approval Not applicable.

Consent to participate Not applicable.

Consent for publication Not applicable.

Conflict of interest The authors declare no competing interests.

\section{References}

Acevedo AM, Perera CL, Vega A, Ríos L, Coronado L, Relova D, Frías MT, Ganges L, Núñez JI, Pérez LJ (2013) A duplex SYBR Green Ibased real-time RT-PCR assay for the simultaneous detection and differentiation of Massachusetts and non-Massachusetts serotypes of infectious bronchitis virus. Mol Cell Probes 27:184-192

Ahmed W, Angel N, Edson J, Bibby K, Bivins A, O'Brien JW, Choi PM, Kitajima M, Simpson SL, Li J (2020a) First confirmed detection of SARS-CoV-2 in untreated wastewater in Australia: a proof of concept for the wastewater surveillance of COVID-19 in the community. Sci Total Environ 728:138764

Ahmed W, Bertsch P, Bivins A, Bibby K, Farkas K, Gathercole A, Haramoto E, Gyawali P, Korajkic A, McMinn BR (2020b) Comparison of virus concentration methods for the RT-qPCRbased recovery of murine hepatitis virus, a surrogate for SARSCoV-2 from untreated wastewater. Sci Total Environ 739:139960

Albastaki A, Naji M, Lootah R, Almeheiri R, Almulla H, Almarri I, Alreyami A, Aden A, Alghafri R (2020) First confirmed detection of SARS-COV-2 in untreated municipal and aircraft wastewater in Dubai, UAE: the use of wastewater based epidemiology as an early warning tool to monitor the prevalence of COVID-19. Sci Total Environ 760:143350

Bande F, Arshad SS, Omar AR, Bejo MH, Abubakar MS, Abba Y (2016) Pathogenesis and diagnostic approaches of avian infectious bronchitis. Adv Virol 2016:1-11

Cai J, Xu J, Lin D, Xu L, Qu Z, Zhang Y, Zhang H, Jia R, Wang X, Ge Y (2020) A case series of children with 2019 novel coronavirus infection: clinical and epidemiological features. Clin Infect Dis 71:15471551

Casais R, Thiel V, Siddell SG, Cavanagh D, Britton P (2001) Reverse genetics system for the avian coronavirus infectious bronchitis virus. J Virol 75:12359-12369

Cavanagh D (2001) A nomenclature for avian coronavirus isolates and the question of species status. Avian Pathol 30:109-115

Cavanagh D (2007) Coronavirus avian infectious bronchitis virus. Vet Res 38:281-297

National Center for Immunization and Respiratory Diseases (NCIRD) DoVD (2021) Symptoms of coronavirus

Gao QY, Chen YX, Fang JY (2020) 2019 novel coronavirus infection and gastrointestinal tract. J Dig Dis 21:125-126

Guerrero-Latorre L, Ballesteros I, Villacrés-Granda I, Granda MG, Freire-Paspuel B, Ríos-Touma B (2020) SARS-CoV-2 in river water: implications in low sanitation countries. Sci Total Environ 743: 140832 
Haramoto E, Malla B, Thakali O, Kitajima M (2020): First environmental surveillance for the presence of SARS-CoV-2 RNA in wastewater and river water in Japan. medRxiv

Holshue ML, DeBolt C, Lindquist S, Lofy KH, Wiesman J, Bruce H, Spitters C, Ericson K, Wilkerson S, Tural A (2020) First case of 2019 novel coronavirus in the United States. N Engl J Med 382: 929-936

Jiang X, Luo M, Zou Z, Wang X, Chen C, Qiu J (2020) Asymptomatic SARS-CoV-2 infected case with viral detection positive in stool but negative in nasopharyngeal samples lasts for 42 days. J Med Virol 92:1807-1809

Katayama H, Shimasaki A, Ohgaki S (2002) Development of a virus concentration method and its application to detection of enterovirus and Norwalk virus from coastal seawater. Appl Environ Microbiol 68:1033-1039

Kocamemi BA, Kurt H, Sait A, Sarac F, Saatci A, Pakdemirli B (2020) SARS-CoV-2 detection in Istanbul wastewater treatment plant sludges

La Rosa G, Iaconelli M, Mancini A, Bonanno F, Veneri BL, Lucentini, Suffredini E (2020a) First detection of SARS-CoV-2 in untreated wastewaters in Italy. Sci Total Environ 736:139652

La Rosa G, Iaconelli M, Mancini P, Ferraro GB, Veneri C, Bonadonna L, Lucentini L, Suffredini E (2020b) First detection of SARS-CoV-2 in untreated wastewaters in Italy. Sci Total Environ 736:139652

Lescure F-X, Bouadma L, Nguyen D, Parisey M, Wicky P-H, Behillil S, Gaymard A, Bouscambert-Duchamp M, Donati F, Le Hingrat Q (2020) Clinical and virological data of the first cases of COVID19 in Europe: a case series. Lancet Infect Dis 20:697-706

Liu W-jW, Yuan C, Yu M-1, Li P, Yan J-b (2020) Detection of novel coronavirus by RT-PCR in stool specimen from asymptomatic child, China. Emerg Infect Dis 26:1337-1339

Lodder W, de Roda Husman AM (2020) SARS-CoV-2 in wastewater: potential health risk, but also data source. Lancet Gastroenterol Hepatol 5:533-534

Medema G, Heijnen L, Elsinga G, Italiaander R, Brouwer A (2020) Presence of SARS-coronavirus-2 RNA in sewage and correlation with reported COVID-19 prevalence in the early stage of the epidemic in the Netherlands. Environ Sci Technol Lett 7:511-516

Mlejnkova H, Sovova K, Vasickova P, Ocenaskova V, Jasikova L, Juranova E (2020) Preliminary study of Sars-Cov-2 occurrence in wastewater in the Czech Republic. Int J Environ Res Public Health 17:5508

Nemudryi A, Nemudraia A, Wiegand T, Surya K, Buyukyoruk M, Cicha C, Vanderwood KK, Wilkinson R, Wiedenheft B (2020) Temporal detection and phylogenetic assessment of SARS-CoV-2 in municipal wastewater. Cell Reports Medicine 1:100098

Pan Y, Zhang D, Yang P, Poon LL, Wang Q (2020) Viral load of SARSCoV-2 in clinical samples. Lancet Infect Dis 20:411-412

Prado T, Fumian TM, Mannarino CF, Resende PC, Motta FC, Eppinghaus ALF, do Vale VHC, Braz RMS, de Andrade JSR, Maranhão AG (2021) Wastewater-based epidemiology as a useful tool to track SARS-CoV-2 and support public health policies at municipal level in Brazil. Water Res 191:116810

Randazzo W, Cuevas-Ferrando E, Sanjuan R, Domingo-Calap P, Sanchez G (2020a) Metropolitan wastewater analysis for COVID19 epidemiological surveillance. Available at SSRN 3586696

Randazzo W, Truchado P, Cuevas-Ferrando E, Simón P, Allende A, Sánchez G (2020b) SARS-CoV-2 RNA in wastewater anticipated COVID-19 occurrence in a low prevalence area. Water Res 181: 115942

Randazzo W, Truchado P, Ferrando EC, Simon P, Allende A, Sanchez G (2020c) SARS-CoV-2 RNA titers in wastewater anticipated COVID-19 occurrence in a low prevalence area. medRxiv

Rimoldi SG, Stefani F, Gigantiello A, Polesello S, Comandatore F, Mileto D, Maresca M, Longobardi C, Mancon A, Romeri F (2020a) Presence and infectivity of SARS-CoV-2 virus in wastewaters and rivers. Sci Total Environ 744:140911

Rimoldi SG, Stefani F, Gigantiello A, Polesello S, Comandatore F, Mileto D, Maresca M, Longobardi C, Mancon A, Romeri F (2020b) Presence and vitality of SARS-CoV-2 virus in wastewaters and rivers. medRxiv

Sherchan SP, Shahin S, Ward LM, Tandukar S, Aw TG, Schmitz B, Ahmed W, Kitajima M (2020) First detection of SARS-CoV-2 RNA in wastewater in North America: a study in Louisiana, USA. Sci Total Environ 743:140621

Tang A, Tong Z-d, Wang H-1, Dai Y-x, Li K-f, Liu J-n, Wu W-j, Yuan C, Yu M-1, Li P (2020) Detection of novel coronavirus by RT-PCR in stool specimen from asymptomatic child, China. Emerg Infect Dis 26:1337-1339

Tavakoli Nick S, Mohebbi SR, Hosseini SM, Mirjalali H, Alebouyeh M (2019) Occurrence and molecular characterization of Torque teno virus (TTV) in a wastewater treatment plant in Tehran. J Water Health 17:971-977

Vilagines P, Suarez A, Sarrette B, Vilagines R (1997) Optimisation of the PEG reconcentration procedure for virus detection by cell culture or genomic amplification. Water Sci Technol 35:455-459

Wang X-W, Li J-S, Jin M, Zhen B, Kong Q-X, Song N, Xiao W-J, Y in J, Wei W, Wang G-J (2005) Study on the resistance of severe acute respiratory syndrome-associated coronavirus. J Virol Methods 126 : $171-177$

Wang C, Horby PW, Hayden FG, Gao GF (2020a) A novel coronavirus outbreak of global health concern. Lancet 395:470-473

Wang D, Hu B, Hu C, Zhu F, Liu X, Zhang J, Wang B, Xiang H, Cheng Z, Xiong Y (2020b) Clinical characteristics of 138 hospitalized patients with 2019 novel coronavirus-infected pneumonia in Wuhan, China. Jama 323:1061-1069

Wang J, Feng H, Zhang S, Ni Z, Ni L, Chen Y, Zhuo L, Zhong Z, Qu T (2020c) SARS-CoV-2 RNA detection of hospital isolation wards hygiene monitoring during the coronavirus disease 2019 outbreak in a Chinese hospital. Int J Infect Dis 94:103-106

Wang W, Xu Y, Gao R, Lu R, Han K, Wu G, Tan W (2020d) Detection of SARS-CoV-2 in different types of clinical specimens. Jama 323 : 1843-1844

Westhaus S, Weber F-A, Schiwy S, Linnemann V, Brinkmann M, Widera M, Greve C, Janke A, Hollert H, Wintgens T (2020) Detection of SARS-CoV-2 in raw and treated wastewater in Germany-suitability for COVID-19 surveillance and potential transmission risks. Sci Total Environ 751:141750

Westhaus S, Weber F-A, Schiwy S, Linnemann V, Brinkmann M, Widera M, Greve C, Janke A, Hollert H, Wintgens T (2021) Detection of SARS-CoV-2 in raw and treated wastewater in Germany-suitability for COVID-19 surveillance and potential transmission risks. Sci Total Environ 751:141750

WHO (2020a) WHO coronavirus disease (COVID-19) dashboard. World Health Organization, Geneva, Switzerland. https://covid19. who. int/. Accessed 5

WHO (2020b) Coronavirus disease 2019 (COVID-19): situation report, 72

Wölfel R, Corman VM, Guggemos W, Seilmaier M, Zange S, Müller MA, Niemeyer D, Jones TC, Vollmar P, Rothe C (2020) Virological assessment of hospitalized patients with COVID-2019. Nature 581: 465-469

Wu F, Zhang J, Xiao A, Gu X, Lee WL, Armas F, Kauffman K, Hanage W, Matus M, Ghaeli N (2020) SARS-CoV-2 titers in wastewater are higher than expected from clinically confirmed cases. Msystems 5

Wurtzer S, Marechal V, Mouchel J-M, Moulin L (2020) Time course quantitative detection of SARS-CoV-2 in Parisian wastewaters correlates with COVID-19 confirmed cases

Xiao F, Tang M, Zheng X, Liu Y, Li X, Shan H (2020) Evidence for gastrointestinal infection of SARS-CoV-2. Gastroenterology 158: 1831-1833. e3 
Ye Y, Ellenberg RM, Graham KE, Wigginton KR (2016) Survivability, partitioning, and recovery of enveloped viruses in untreated municipal wastewater. Environ Sci Technol 50:5077-5085

Zhang J, Wang S, Xue Y (2020a) Fecal specimen diagnosis 2019 novel coronavirus-infected pneumonia. J Med Virol 92:680-682

Zhang W, Du R-H, Li B, Zheng X-S, Yang X-L, Hu B, Wang Y-Y, Xiao G-F, Yan B, Shi Z-L (2020b) Molecular and serological investigation of 2019-nCoV infected patients: implication of multiple shedding routes. Emerg Microb Infect 9:386-389
Zheng S, Fan J, Yu F, Feng B, Lou B, Zou Q, Xie G, Lin S, Wang R, Yang X (2020) Viral load dynamics and disease severity in patients infected with SARS-CoV-2 in Zhejiang Province, China, JanuaryMarch 2020: retrospective cohort study. BMJ 369:m1443

Publisher's note Springer Nature remains neutral with regard to jurisdictional claims in published maps and institutional affiliations. 